\title{
Research On The Hybrid Teaching Method Of Ideological And Political Course Online And Offline In Higher Vocational Colleges Under The Background Of Internet
}

\author{
Jihua Wen ${ }^{1}$ \\ ${ }^{1}$ Shangrao Preschool Education College, Shangrao, Jiangxi, 334000, China
}

\begin{abstract}
In the 21st century, the rapid development of the Internet has affected all walks of life to varying degrees. In the era of rapid development of the Internet, the ideological and political teaching of higher vocational colleges lags behind the development of the times. Whether from the aspects of ideological and political teaching content, ideological and political teaching means or teaching teachers' accomplishment, how to better use the Internet to meet the teaching requirements of the new era is undoubtedly a major problem that higher vocational colleges need to think about in the teaching industry, so higher vocational colleges should seize the opportunity, face the difficulties and comply with the requirements of the new era, Construct the teaching theory system of ideological and political course with characteristic socialism.
\end{abstract}

\section{Introduction}

On this basis, this innovative teaching method has brought resources and convenience to ideological and political education in higher vocational colleges, but at the same time, this new education model is not a profit without harm. He also brings crisis and challenge to our university education system. Therefore, teachers in higher vocational colleges should deeply explore the ideological and political teaching system, so that online and offline hybrid teaching is better convenient for students and teachers. Teachers must have a sense of crisis, clearly recognize the changes brought by the Internet to the ideological and political education teaching system of major higher vocational colleges, and clearly recognize the advantages and disadvantages of mixed teaching to ideological and political teaching, in order to better improve our ideological and political teaching system [1].

\section{Importance of Ideological and Political Teaching Reform in Higher Vocational Colleges Under the Influence of Internet}

\subsection{The Basic Discussion of Internet}

The rapid development of the Internet has spawned a new model of Internet. The influence of Internet has penetrated into all walks of life in the society and has a very vigorous vitality. He has brought great convenience to the production and innovation of various industries. As a vigorous and easy-to-operate Internet network platform, he has many advantages, such as humanization, green, innovation, resource sharing. Internet is a new Internet model, supplemented by various industries in society." Internet ideological and political" is the integration of electronic network information technology and ideological and political teaching system. Using the resources provided by the Internet to make the content of ideological and political teaching more interesting, so that students can learn more actively and improve the quality of ideological and political teaching.

\subsection{The Importance of Ideological and Political Teaching Innovation in the Context of Internet}

A 2015 guidance on the State Council pointed out that most of the future teaching methods are carried out on the Internet, which is also the profound impact of the rapid development of the Internet on the education industry. Ideological and political theory course has always been an important course in the education and teaching system, whether it is the ideological and moral character of primary school, the politics of middle school or even the ideological and political course of university. How a person has the correct values, world outlook, outlook on life in addition to the cultivation of the family is more the school's teaching, and the school's teaching is always inseparable from the great impact of thought and politics[2]. The correct ideology is the most important link in the education and teaching work of higher vocational colleges. Therefore, higher vocational

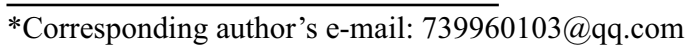


colleges should promote the innovation of education and teaching in time, make better use of the mixed mode of Internet online and offline teaching.

From a student's point of view, the development of the Internet has also brought great convenience and benefits to students. Using the massive resources of the Internet, students have increased their interest in learning and broadened their horizons. Cultivate their multi-angle thinking model. But in the same way, the massive resources on the Internet have brought troubles and challenges to students. Some college students do not have mature thinking ability, in the face of all kinds of good and bad information on the Internet, they do not have enough ability to distinguish right from wrong, they do not have strong self-discipline ability, once attracted by bad information, They unconsciously fall inside, or even for a long time. Light makes them indulge in the network, bring bad influence to their life and health, heavy bad information can even distort the outlook on life, world outlook and values of contemporary college students. If students are not correctly guided in the face of all kinds of intermingled Internet information[3], it is difficult to shape students' correct three views and have an irreversible impact on their physiology and psychology. In the new era of information explosion, for young college students who do not contact with complex society, all kinds of temptations on the Internet have also brought new challenges and problems to the teaching of ideological and political education. How to better make the ideological and political courses have a deep influence on the students is a difficult problem urgently needed to be solved in the higher vocational colleges.

\section{Current Situation of Ideological and Political Teaching in Colleges and Universities under the Background of Internet}

\subsection{Problems in Ideological and Political Teaching}

Many times of ideological and political teaching reform has made the ideological and political teaching of our country to a certain development, to have the development will have the difficult problem. Nowadays, ideological and political teaching in higher vocational colleges is faced with a very awkward problem. Ideological and political teaching is a boring course, so it has produced the following common situation in higher vocational colleges. Even many students do not want to go to ideological and political. In addition to the software equipment is not ideal, the hardware equipment of higher vocational colleges also has many defects. Especially for more remote areas or third-and-fourth-tier cities of higher vocational colleges. In addition to the shortage of hardware equipment, the above higher vocational colleges have not made full use of the mixed teaching mode of Internet online and offline.

\subsection{The mode dilemma of ideological and political teaching students getting along with each other.}

As a theoretical course, teachers in colleges and universities pay more attention to the theoretical knowledge in books and ignore the practical teaching in ideological and political teaching. Boring theoretical teaching makes students lose interest in ideological and political courses, teachers and students fall into a cycle of death. From the point of view of teaching means, there are also great difficulties in the mode of students getting along with each other. In the Internet online and offline mixed teaching mode, teachers can use the massive resources of the Internet, such as pictures, video, audio and students to analyze and discuss the current social hot events, improve students' interest in ideological and political courses and improve the quality of ideological and political teaching. But reality is always more difficult than imagination. For remote areas and third-and-fourth-tier cities, colleges and universities do not attach great importance to ideological and political courses[4]. A large number of students simply can not participate in the discussion of social hot events, teachers and students interaction difficulties or substantive changes. Therefore, the mode of teachers and students getting along with each other, the content of ideological and political teaching and the way of ideological and political teaching all need to be greatly innovated. The teaching method of students' listening is no longer in line with the educational concept of contemporary society. Ideological and political teaching should closely follow the development of the times, determine good goals and development directions, carry forward their own strengths, strive to train talents, and find out a line of sustainable development.

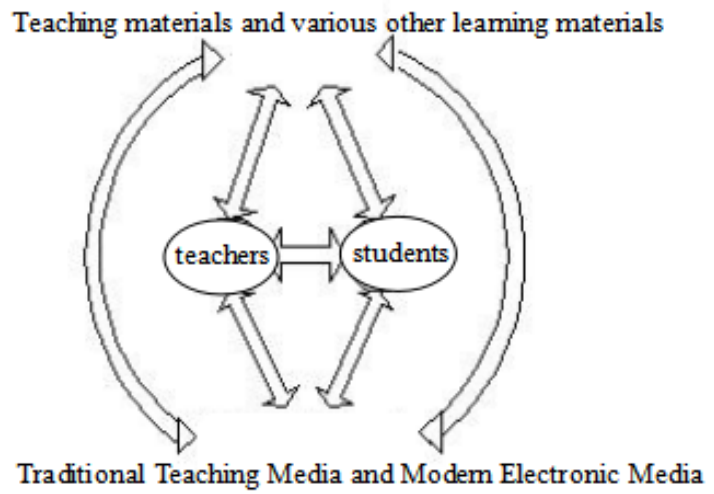

Figure1: The Tnteraction Between Teachers And Students 


\section{Methods of Ideological and Political Teaching Reform in Higher Vocational Colleges Under the Background of Internet}

\subsection{Introduction of Modern Multimedia Teaching Equipment}

In recent years, the Internet has developed rapidly, especially in the 5 th $\mathrm{G}$ of 2020 . In order to make the education industry closely follow the trend of the new era, all higher vocational colleges must introduce the Internet ideological and political online and offline mixed new teaching mode, this reform scheme should become the focus of the education work of higher vocational colleges. In order to make ideological and political theory go deep into students' life, expand the coverage of students' groups, and increase the influence on students' groups, Ideological and political teachers in higher vocational colleges must make full use of our commonly used communication tools to build a bridge between themselves and students. During recent years, WeChat, qq, Weibo and other communication tools have developed rapidly and are popular with young users [5]. Teachers in higher vocational colleges can use these hot communication tools to expand ideological and political theory. For example, create ideological and political class group, create WeChat public number, create Weibo account to strengthen the exchange of ideological and political theory with students. This method can not only bring into the students and teachers about, put an end to the teachers do not know the students, students do not know the embarrassing scene of teachers, improve students' interest in ideological and political classes, let them feel that ideological and political classes are no longer boring. Secondly, it can also make ideological and political theory go deep into the students' life bit by bit, deepen the influence of ideological and political theory on their three views, and help to improve the teaching quality of ideological and political teaching.

\subsection{Using the Internet to expand the new platform of ideological and political courses and strengthen the interaction between teachers and students.}

The rapid development of the Internet has spawned many new platforms for the development of the Internet. Education departments can use the Internet to create a network forum for ideological and political theory that facilitates the communication of schools, teachers and students. To provide students with more methods of ideological and political teaching, increase their interest in ideological and political theory education. Higher vocational colleges can also use the massive resources and information provided by the Internet to broaden students' horizons for ideological and political teaching and cultivate their thinking mode of multi-angle thinking. The rapid development of the Internet has brought us opportunities and challenges [6]. In the era of information explosion, the resources provided by the Internet are not all good resources for suitable students. When teaching, teachers in higher vocational colleges must choose the resources and information that accord with the socialist thought, can carry forward the main melody of the society to let the students discuss, shape the students' proper three views, and let the students have a positive heart. There are many pitfalls and temptations on the Internet. A casual window message on a computer may also make a student plunge into the abyss. For students, they must resist temptation consciously. For teachers, we must guide students correctly. For schools, we must adopt some desirable methods to make the Internet safer and greener. At the same time, higher vocational colleges should also strengthen the supervision of campus network.

\subsection{Using Innovating Educational Idea and Increasing Ideological and Political Practice.}

The rapid development of society makes our ideological and political teaching concept can no longer be single, rigid or even boring. For the content of ideological and political teaching, mastering theory is no longer the only element. In teaching, teachers in higher vocational colleges should strengthen students' understanding of it, and let students learn to apply theory to practical operation. Instead of cramming the theory to cope with the exam. Teachers should adopt a variety of teaching methods to broaden students' social horizons, to enhance students' social ability, to cultivate students' multi-dimensional thinking methods, and to shape their outlook on life. World outlook, values three correct, innovative ideas, in line with the needs of modern social industries.

The traditional ideological and political teaching, which attaches importance to theory and neglects practice all the time, thinks that ideological and political courses do not want science and engineering, there is no practice, only to master the theory, this is a very rigid teaching method. The Internet has spawned a series of new media, which can be used to improve the quality of ideological and political teaching. According to the background of Internet, the mixed teaching mode of ideological and political online and offline should be as follows: first, the means of ideological and political teaching should be closely combined with Internet equipment. At the same time, we should use various hot social app to enrich their teaching content. Each major higher vocational teacher can strengthen the efficient contact with students online and offline through a series of methods such as network teaching platform, Weibo hot account and qq. Teachers can publish some of the latest and hottest social hot events in these new media platforms, so that students can analyze and discuss their views on these social hot events through what they have learned. In this form to exercise students' rational thinking ability. Second, teachers can make students learn all the time through Internet equipment, use fragment time to learn ideological and political theory, now Weibo, WeChat and a series of hot money app 
deeply liked by students, contemporary college students like to browse the latest news on these apps, express their own unique views, record their feelings, On this basis, teachers in higher vocational colleges must skillfully operate these hot money app, and think about how to connect ideological and political education theory with these hot money app. Closely follow the social trend, to create a new socialist ideological and political teaching system.

\section{CONCLUSION}

With the rapid development of society and the rapid development of the Internet, the Internet ideological and political online and offline hybrid teaching model has brought a lot of convenience to our education system, but opportunities are also facing challenges. Higher vocational colleges must keep up with the trend of socialist era, master students' psychology and work together to build a theoretical system of ideological and political education in line with the new trend of socialism.

\section{Acknowledgement}

Discussion on the Reform Practice of the Mixed Teaching Mode of Ideological and Political Course in Colleges and Universities Based on Mobile Information Technology Research GJJ191255 Science and Technology Subject Numbering in Jiangxi Province

\section{REFERENCES}

1. Kang,Y.L.(2016)Research on the Teaching of Ideological and Political Theory in Colleges and Universities under the Environment of Internet[J]. Contemporary Educational Practice and Teaching Research.

2. Zhang, H.Y.(2016)Thinking on the Teaching Reform of Ideological and Political Course in Higher Vocational Education under the Background of Internet[J].Training in China.

3. Wei,X.X.(2015) Internet Ideological and Political Course: Implementation and Innovation of Ideological and Political Teaching in Colleges and Universities under the Network Environment [J].Journal of Social Sciences, Jiamusi University.

4. Zhao,Y.J.Guo, J.J.On the Reform of Ideological and Political Teaching in the Context of Internet[J]. Modern economic information.

5. Wu,L.M.(2016)Teaching Thinking of Ideological and Political Course Reform in Colleges and Universities under Internet[J]. Asia-Pacific Education.

6. Peng,L.(2016)A Preliminary Study on the Teaching Reform of Ideological and Political Theory Course in Universities under the Thinking of Internet [J].Journal of Southwest University of Science and Technology. 